\title{
Human Development and Capability Building in the Niger Delta: Issues and Challenges
}

\author{
Otega Okinono 1 \\ Dani Salleh² \\ Badariah Hj Din ${ }^{3}$

\begin{abstract}
${ }^{1}$ School of Government, College of Law, Government and International Studies (COLGIS), University Utara Malaysia (UUM)
${ }^{2}$ Department of Planning and Property Development, School of Government (COLGIS), University Utara Malaysia (UUM) ${ }^{3}$ Department of Public Management, School of Law, Government and International Studies (COLGIS) University Utara Malaysia
\end{abstract}

\section{Doi:10.5901/mjss.2015.v6n6s2p406}

\section{Abstract}

Continuous destruction of the Niger Delta region of Nigeria environment by oil-related exploration, unemployment, human development and education has persistently caused unrest and violence. Despite the laudable strategies adopted by the government in ensuring lasting solution in the region, scholars have however criticized some of the strategies as not working and impacting in the lives of the target population. This paper therefore explores human development and capability issues in achieving sustainable community development in the region. In-depth interview was used to investigate the issues in six communities in three selected states and NDDC. The result of this study revealed that issues like insufficient funding, projects abandonment, community attitude and leadership style are the major impediments to sustainable human development in the Niger Delta. It is therefore recommended that both governmental and non-governmental developmental agencies should take into cognizance issues like proper funding, monitoring and evaluation of projects and community involvement in designing and implementation of development plans. Likewise, community should see themselves as developmental partners with development agencies by way of developing positive attitude and maintenance to developmental projects.

Keywords: human development, capability building, community development, NDDC, oil producing community.

\section{Introduction}

The Niger Delta region is amongst the six geo-political regions of Nigeria which is naturally endowed with high deposit of oil that has been a focus of interest for the Nigeria government and multinational oil corporations. Due to the natural endowments of the Niger Delta, it is expected that the region experience economic regeneration and prosperity, human development, social stability, and peaceful political atmosphere. The region generates over $95 \%$ of Nigeria foreign exchange, $85 \%$ of the country annual income and approximately $40 \%$ of Gross Domestic product(Babatunde, 2012). This placed Nigeria as the highest oil producing Nation in Africa and 11 th in the world (Okumagba, 2011; Okpo \& Eze, 2012; Ojo, 2012; Obi, 2014). Consequently, the presence of multinational oil firms operating within the region ought to bring about considerable social and economic development through corporate social responsibility. Although, the Nigeria government has established Niger Delta Development Commission (NDDC) to facilitate rapid and sustainable developmental projects within the region especially on ecological, human development and infrastructural developments. More recently, Nigeria government has reinforced her efforts in the region by granting amnesty to militant youths and establishment of the Niger Delta Ministry to formulate and coordinate policies and programmes for the development, peace and security of the region. These initiatives are meant to create a socially, economically, politically, ecologically stable and peaceful environment within the region. However, development in the region is not proportionate with the level of its contribution to national income and does not reflect the enormous financially commitments and efforts made by both federal and state governments of Nigeria (Obi, 2014 \& Kaur, 2013).

Therefore, it is not surprising that the consciousness of exploitation, marginalization, disempowerment and underdevelopment made the Niger Delta a region a violent prone area due to deep rooted frustration and manifestation of negligence by both the government and oil multinationals. This is because the major root causes of unrest and violence in the region which are continuous destruction of the region environment by oil-related exploration, unemployment, human development and education have not been adequately addressed by Nigeria government and non-governmental agencies (Agbiboa, 2013; Duru \& Ogbonnaya, 2012; Davidheiser \& Nyiayaana, 2011; Ibaba, 2011). This has made the 
region to be one of the most underdeveloped and poor region not only in Africa but also among oil producing regions in the world

The United Nation Development Programme report of 2013 indicated that the human development index of the region is at 0.433 compared to other oil producing communities like Gabon, Libya and Malaysia are put at $0.668,0.791$, and 0.791 respectively. Also, Eneh (2011) reports shows disparity in access to social amenities amongst the six geopolitical zones in Nigeria. The study indicates that there is low rate of access to literacy and secondary education compared to other non-oil producing regions. While the Niger Delta region has 87.9 percent access to youth literacy and 70.3 percent on secondary education whereas, in the south-West where there is no oil it has 94.7 percent and 87.5 percent respectively. Also in the area of unemployment the region has the highest with 9.5 percent while the North-East 3.2 percent, North-West 22 percent, North-Centre 4.3 percent, south- East 6.6 percent and South-West 4.5 percent respectively. Likewise report from the Niger Delta Environmental survey 2010 shows that the ratio of primary school to people leaving within communities in the region is I primary school to 3,700 people serving 3 or more communities while that of secondary school is 1 to 14,679 people which is 1 school to 8 or more communities.

The marginalization, poor infrastructural and human development progress of the Niger Delta has not gone unnoticed by successive governments in Nigeria. Since the late 1950's, the Niger Delta has been recognized as a region requiring special developmental attention (Osuoka, 2007). A number of special agencies have been created by the Federal Government to address development in the region. The first of its kind was the Willinks' Commission which was set up in 1957 to investigate and look into the problems of the region. Another agency was also set up in the name of Niger Delta Development Board (NDDB) established in 1960. Thereafter Niger Delta Basin Development Board, established in 1965 and the Oil Minerals Producing Areas Development Commission, established in 1992 were also established to address the developmental needs of the people of Niger Delta. All these agencies failed woefully to impact on the lives of the people due to corruption, partisan politics, mismanagement and lack of funds (Jack-Akhigbe, 2013).

Despite the laudable strategies adopted by the government in ensuring lasting solution in the region's underdevelopment, scholars however criticized some of the strategies. For example, Aghedo (2013) argued that the postamnesty in Niger Delta failed because the programme was not targeted toward community and human development rather as way to entice the militants to give up their arms. Similarly, Dode (2012) suggested the need for government to adopt the approach of community participation and capability building in developmental agenda in the region. Therefore one of the critical gap this study intend to fill is what Dode (2012) identified as lack of strategic method, greed and bad governance in Nigeria as factors contributing to the region underdevelopment, unemployment and poverty in the midst of her rich natural resources. Conclusively, Davidheiser and Nyiayaana (2011) maintained that there is incessant unrest and violence in the region due to government failure to incorporate robust strategy of peace building. They argued that human development and capability building is a vital tool in restoration of peace and tranquility for sustainable development to any warring community.

Although recently Nigeria government has exerted more efforts in the area of capability building through vocational and non-vocational training within and outside the country but despite this much concerted efforts by government most of those trained youths are still relocating back to the creeks due to joblessness (Ubhenin, 2013). This indicates that sustainable human development is achievable when it is all encompassing.. This implies human development is not all about enhancing capabilities through education alone rather people must be adequately integrated into society. Human development and capability building defines the process by which a society usurps the natural surroundings to its advantage for development (Nussbaum, 2001). It depicts that insensitivity to the needs and demands of a teeming population without giving considerable attention to social and economic well-being will lead to underdevelopment. Various studies that addressed human development and capability approach on marginalized and poor people (Fukuda-Parr, 2011; Gries \& Naudé, 2011; Sen, 2005). However, very few works focus on the issues of marginalization among the oil producing communities. Although, Chinyere and Stephen (2013), Gilbert (2013), Naanen (2012) Ukiwo (2011), Courson (2011) and Oluwaniyi (2010) have studied on the marginalization of the Niger Delta, yet, none of these studies explicitly profound human development and capability issues in relation to access and availability of infrastructure in the crises of the Niger Delta region. Therefore, this study aims to explore issues and challenges surrounding human development and individual capability as an instrument of community transformation in the Niger Delta particularly the oil producing communities of the region. The study will specifically focus on the activities of Nigeria government to create both economical and infrastructural developments in the region through the Niger Delta Development Commission (NDDC). 


\section{Literature Review}

\subsection{NDDC and Human development}

The NDDC specifically created to ensure the overall development of the Niger Delta. This is premised on the paradigm which emphasized the relevance of people as the focus of development in society. Human development is measured by variety of indicators such as longevity, education and a decent standard of living (UNDP, 1996). It is worthy to note that human development in the Niger Delta as a whole is in a sorry state. The presence of infrastructures in the Niger Delta region does not reflect in well-being and the improvement of the people socially and economically. The basic infrastructure needed to facilitate economic and human development is almost not available. This is attributable to government attitude towards policy implementation and strategic action plan for development programmes (Oviasuyi \& Uwadais, 2010). Mahbub (2006), posits that the wealth of a nation is not dependent on its income alone but how such wealth is able to transcend the objectives and interests of the people through access to basic requirements of life. Human development therefore, is the ability of individuals to be able to maximize their potential through freedom of choice for self-actualization in life. Akpabio and Akpan, (2010) contend that despite the huge revenue generated from oil in the Niger Delta region the level of development is not proportionate with people's living condition. Human development goes beyond economic well-being; it is the ability to identify the needs and interests of the people in order to equip them by enhancing their choices and exercising freedom on matters that affect their lives. The real wealth of a nation therefore is premised on how well the individuals are able to maximize their capabilities through access to basic needs of life.

Human development therefore is the ability of the individuals to have freedom to choose the mode of life that will enable them to become what they aspire for in life (Chandler, 2013). A meaningful assessment of human development in the Niger Delta region should take into consideration important issues such as access to education. UNDP (2006) reported that there is a disconnection between availability and utilization of educational skills and knowledge in the area of expertise in the Niger Delta. The report also indicates that the educational system in most part of oil producing communities is grossly affected as a result of improper coordination of investment that will affect positively the educational needs and interests of the people of Niger Delta Region. Alongside the education, the development planning in any area or community must involve the people in decisions that affect them. This is to ensure that developmental programmes are tailored towards the needs and wants of the people and not otherwise. This will enable the people to situate their problems holistically based on their interests and values (Alkire, 2002).

One of the major root causes of the inefficiency of the intervention agencies like NDDC was traced to the faulty foundations on which these intervention agencies were established (Paki \& Ebienfa, 2011). More so, the lack of autonomy by agencies in the region on revenue allocation and implantation of projects is one of such root cause as their major duty is basically supervision of projects that they do not have any idea of its origin. Similarly, Corruption and lack of political will, insufficient funding and poor monitoring projects were also identified (Ite, 2007; Jack-Akhigbe, 2013; Mähler, 2012).

\subsection{Capabilities building and Human development}

Capability encompasses the level at which individual's mental and intellectual being is being developed to cater for the needs of society and man (Frediani, Boni and Gasper, 2014). The individual capability has been identified as the core value in achieving one's ends in a particular society; this is because it enlarges the choice of individual. It is more of moral approach than ethics as it seeks to provide the individual with necessary ingredients to live a desired life. Developing human capability is the ultimate position of human development approach and this gives freedom to individual to choose among the available opportunities in the society.

Capability is the ability to perform or achieve certain outcomes through a set of controllable and measurable factors, features, processes or services (Amartya, 2005). Human development therefore is achievable when people are given when people are given ample opportunity to actively participate and given freedom to make choices in issues that affects their life. Individuals are considered as both an end and a means with the ability for choices and freedom among a multiplicity of values (Dopkesi \& Ibeizugbe, 2012). Developmental agencies such as NDDC should support the development of capabilities, but not influence their functioning giving individual's freedom to choose how to exercise their capabilities for themselves. Till date, development agencies have failed to galvanize people into optimally productive activities most especially in display of skills and expansion of their abilities. The human development agenda is a peoplecentered development that seeks to remove impediments that prevent people from achieving their full potentials and to empower people particularly at the grass root level towards reducing inequalities of all kinds, including those relative 
location, gender and generation and to enlarge peoples choices in the political, economic, social and cultural realms (Apkomuvie, 2011). A human development agenda is capable of transforming the Niger Delta into a region that is economically prosperous, socially stable, ecologically regenerate and politically peaceful. This will ensure rapid, equitable and sustainable development.

\section{Methodology}

The study utilized the qualitative research method with in-depth interview approach in other to adequately investigate the level of impact of developmental programmes and activities on community sustainability and transformation within the members of the community. The convenience sampling method was used. The study interviewed 19 community members consisting of Community Development Committee (CDC) leaders, youth leaders, opinion leaders and women leaders within community in six communities within the Niger Delta region in Nigeria. Also, three key officers from Niger Delta Development Commission (NDDC) were interviewed between May and October 2014. Data was analysed thematically using Nvivo 10 software. Results from the interviews was generated from the coding frames consisting of conceptualized elements that explained the perceptions and experiences of the interviewees on the impact of the activities of NDDC in the Niger Delta. Furthermore, sub-themes were developed in other to have an in-depth understanding and consistent findings to the research question; the challenges of sustainability of development programmes by NDDC in the Niger Delta.

\section{Results}

From the interview analysis, the major issues with human development and capability building in the community were identified. The main purpose of this is to investigate how community sustainability and transformation can be achieved within the members of the community. The interviewees disclosed all the issues that are behind the underdevelopment and poverty in their community. The emerged issues were categorized into four sub - themes that were in-putted into the QSR Nvivo data management program. The emerged perceptions of the interviewees grouped into sub sub-themes and discussed in detail below are; abandonment of projects, community attitude, lack of adequate funding, leadership problem.

\subsection{Impediment to sustainable human development in the Niger Delta}

Generally, some literatures have identified lack of participation and involvement as one of the major factors that hinders sustainable human development (Akpomuvie, 2011). According to Thomas, Narayanan, Wheeler, Kiran, Joseph and Ramanathan (2012), the extent to which community participate in developmental plans is crucial to sustainability of that project. The findings showed that community participation play significant role in achieving sustainable human development as indicated in the figure 1 below.

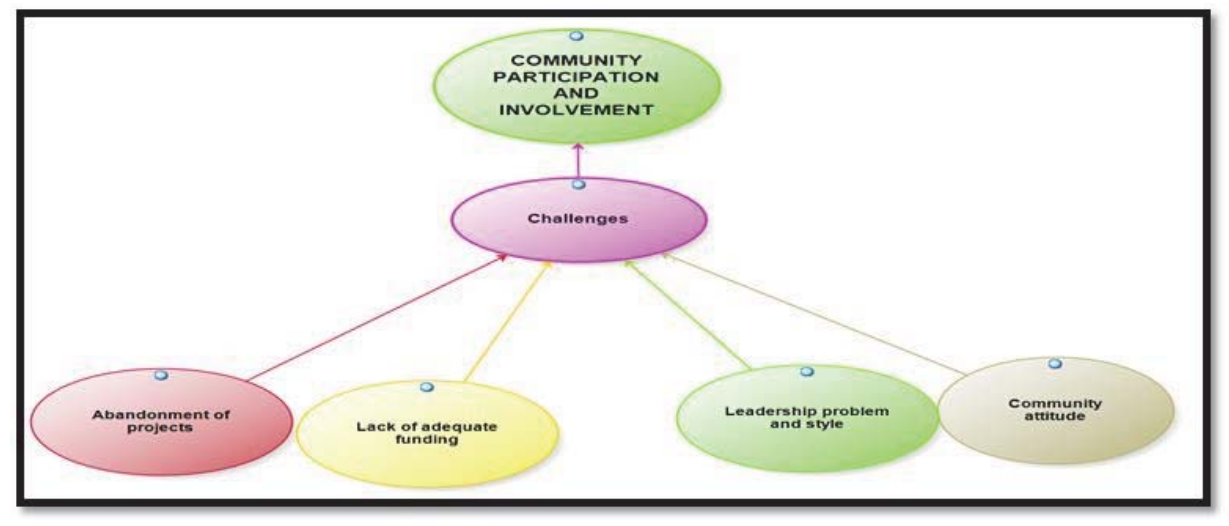

Figure 1: Thematic mapping of challenges to sustainable development 


\subsubsection{Lack of adequate funding}

Generally, lack of adequate funding has been identified as a major challenge to achieving meaningful sustainable development in Nigeria (Jack-Akhigbe, 2013). Confirming this view an NDDC staff, interviewee 22 noted thus, "So when it now comes to implementation, the money is the problem". This claim was also confirmed by another NDDC personnel, Interviewee 21 who reiterated the ideology behind the establishment of the NDDC but which was unable to function properly due to financial constraints. He revealed that:

The ideology behind these entire programme was to train these people and get them started with Starter Park but because of the lack of funding, so a few percentage of them were able to be empowered, majority of the group were left which also is as a result of lack of funding. NDDC has a wonderful mandate but because of lack of funding we cannot execute all these (Int. 21).

Stressing on the need for economic empowerment, he noted further that, "NDDC's efforts in empowering community is being hindered as a result of insufficient funding"

Meanwhile, interviewee 18, a community leader, pushed the blame on NDDC which he accused of not empowering community members after training. He specifically revealed that:

As for the skill aspect like scholarship, it is not working I have not seen anybody that benefited from NDDC skill here. Because in NDDC you will go for training and at the end you go home with nothing. What is the use of the training when after you are trained no empowerment? (Int. 18).

In the same way, interviewee 15 , another community member, faulted NDDC claim and blamed the persistent agitation on their insensitivity to issue of human development. He claimed that, "in my place we have not felt the impact of NDDC in the area of human development so much is still expected. We can even go around so that you can see".

However, interviewee 21, an NDDC staff, suggested that instead of depending on financial support, the issue of capacity building for oil producing communities should be taken seriously. He observed that, "engage them in capacity building to make our people to be useful to themselves, for them to be self-empowered, for them to be self-employed".

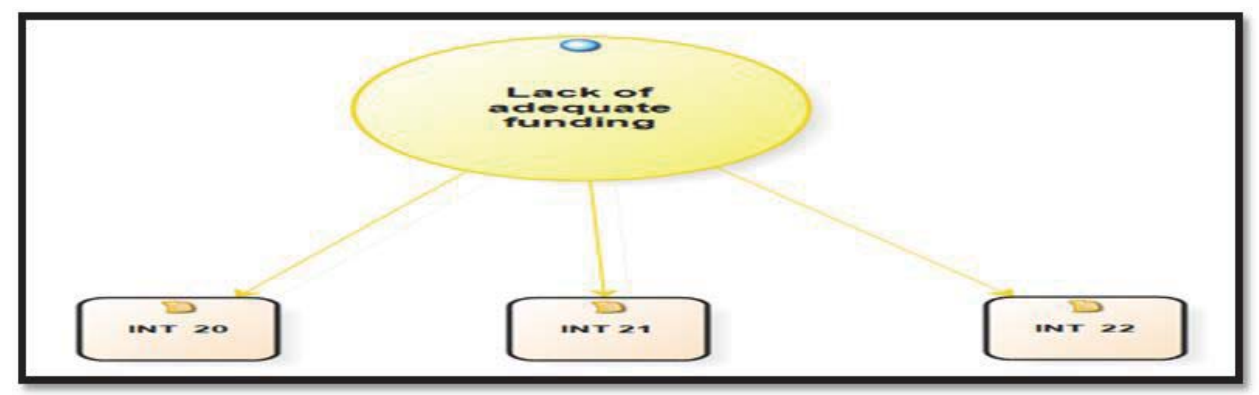

Figure 2: Lack of adequate funding as a challenge to sustainable human development.

\subsubsection{Abandonment of Projects}

As identified by the interviewees, the abandonment of projects by developmental agencies is one of the challenges to sustainable development in oil producing communities. This finding corroborates the position of Ingwe, Mboto and Ebong (2012), Agbu (2012) that most developmental projects in Nigeria especially in the Niger Delta region are deficient due to abandonment. According to a community leader, interviewee 1, the community is not happy because:

We are not satisfied, because most of the projects they are doing are all uncompleted projects, like the water tank they built in this community; they were trying to lay their pipeline ask anybody here they will tell you, except they (NDDC) will come and say this is what we want to do for you as a community, this is how we want to do it (Int. 1).

However, interviewee 22 one of NDDC official while offering solution to the challenges of sustainability suggested that,

The only thing we can do to sustain programmes and project is by follow up and periodic monitoring and maintenance but how can we do this when we don't even have enough money to complete some of the projects we have started? 


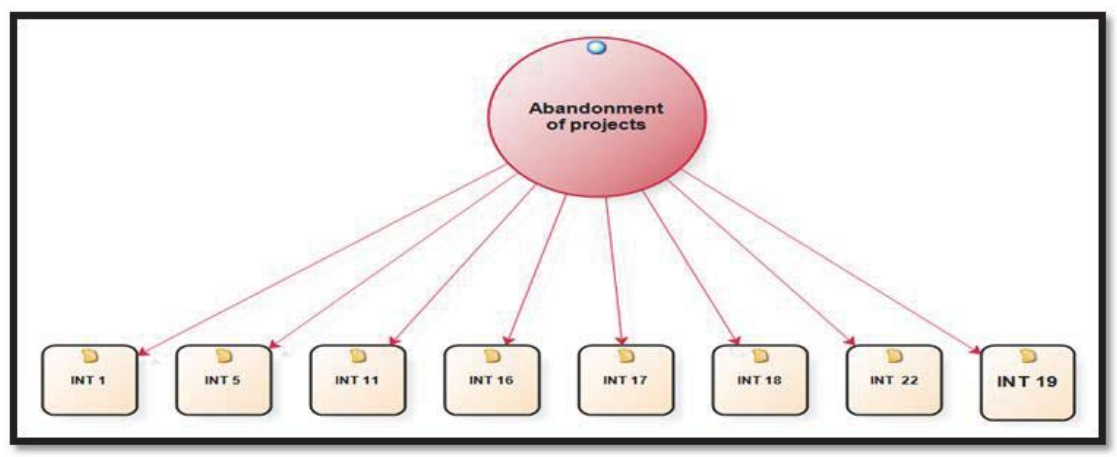

Figure 3: Community perception of abandonment of projects as impediment to sustainable human development

\subsubsection{Community Attitude}

Another factor that was identified as posing a challenge to sustainable human development is community attitude. Community attitude plays an important role in determining the level of participation and sustainability in developmental initiatives. Therefore, Assante, Lottig and Hotels (2012) stressed that there is need to understand community attitude and perception in development initiatives in order to enhance their level of involvement and sustainability. Stating the fundamental issue behind the challenges of human development, interviewee 22, NDDC officer divulged that,

Most time these communities don't even show interest in some of all these programmes even when they do no commitment. For example, when we go out for skill acquisition and training programmes in communities, after the training we give them some materials called starter packs to start with, at the end you find out that they don't even use these materials some even sell them. So when this occur there is nothing NDDC can do (Int. 22).

Similar opinion was expressed by Interviewee 21, NDDC officer on the impact of community attitude towards NDDC programmes for development.

It can be very frustrating when communities are not in support of whatever you want to do for them. If it is a violent community they might even chase you away but when you make them part and parcel of any development programme they will take it as their own thing. But there are times we have problem in trying to educate them on a particular programme (Int. 21).

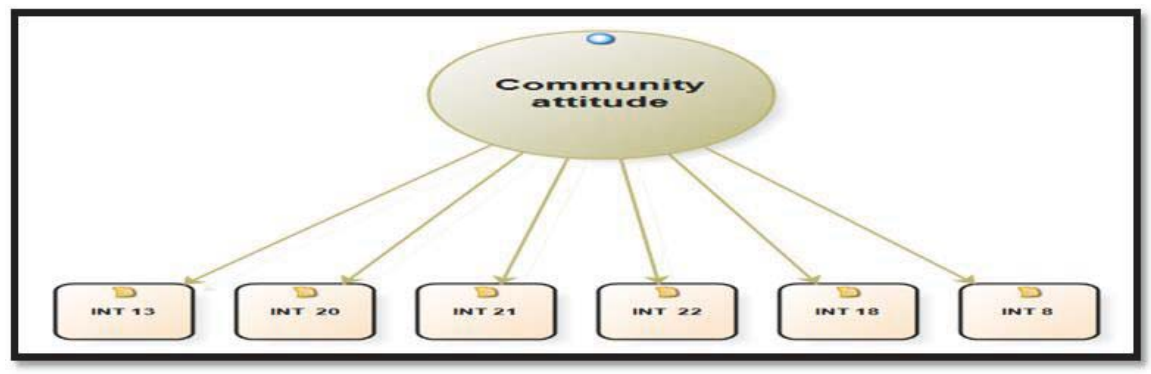

Figure 4: Community attitude as a challenge to development.

\subsubsection{Leadership style/ problem}

The leadership style of both the community and NDDC was identified as one of the major hindrances to sustainable peace and development. This finding is in line with the views of Ololajolu (2000), Paki and Ebienfa (2011), that failures of developmental agencies is attributed to ineffective system of governance whereby there is no autonomy in allocation of revenue and projects by the agencies in their system of operations. This affects the mode of operations of development agencies in allocation and implementation of projects. Similarly, this problem was also attributed to the community 
leadership style which has been a challenge to sustainable development in the Niger Delta. Buttressing this view, Interviewee 7, a community leader narrated;

Because of the longtime negligence, the system before was also hijacked by few leaders in the community who take little money from the oil companies operating here and government and silence the other people in the community. It is now the communities are waking up to see that these things most stop. If you know you are coming to represent us and you cannot give us what we want, we don't want you to represent us, they are now waking up to it. We are now realizing that if we must learn to do something, we must communicate (Int. 7).

Also, Interviewee 10 from the community lamented thus;

One major reason is because of time frame/tenure given to incoming executives to work who may not actually have enough time to finish all their plans before another executives comes in. Change in leadership and insufficient time given to executives to work is a problem for us in community (Int. 10).

Corroborating this claim, NDDC official, interviewee 20 also stated the key challenges;

Leadership problem in the community is also affecting us. You will train one set of CDC, build their capacity to understand the workings of the system, by the time they are working with NDDC the next thing you see is that they have been removed and a new set has come so you have to start all over. While in NDDC, Because of the political influence, they are appointing anybody to the board, they have not been looking at competency. So the place is manned by inexperienced and unqualified people. So, all these have really affected the system (Int. 20).

Likewise interviewee 21 another NDDC official reiterated that, "Lack of interest on the part of the communities and the representatives. Many a time the representatives are seen to be failures (sic) to the people and you cannot break the position of the representatives".

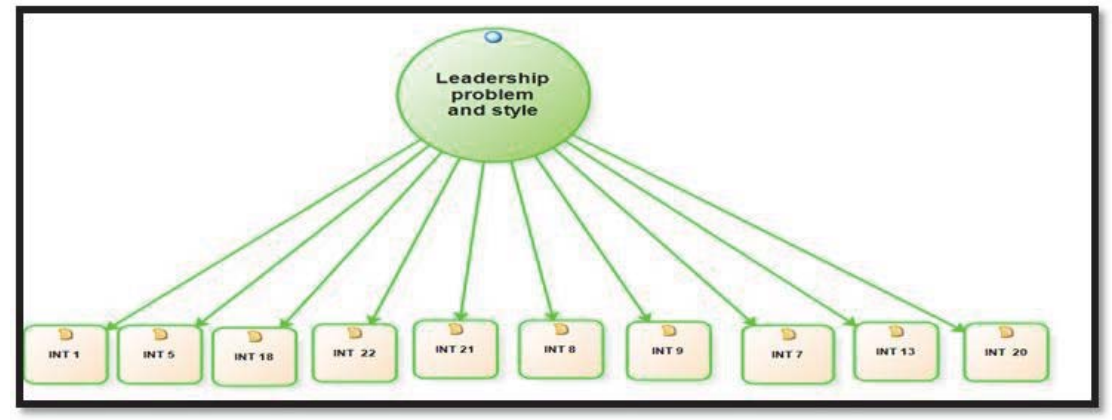

Figure 5: Leadership style and structure as an impediment to development

\section{Discussion and Recommendation}

This study explores the issues of community development and its impact on human development and capability building in the Niger Delta. In relation to the objective of the study, the impediments to human development and sustainability were established as: abandonment of projects, community attitude, lack of adequate funding and leadership problem. These major challenges to human development need to be adequately addressed by government in implementation of developmental projects to achieve sustainable development that places the individual as the focus of development. Because, for instance when development projects are abandoned, the community members are automatically deprived of anticipated changes and benefits which by implication results to persistent low standard of living. Lack of adequate funding, another finding which emerged from this study is a major challenge to effective implementation and sustainability of developmental projects. Similarly, community attitude impedes the developmental efforts meant to improve on the conditions of the people. For instance, Hanafiah, Jamaluddin, \& Zulkifly, (2013) in their study noted that the attitude of community members is paramount to effective implementation and sustainability of development initiatives. Therefore, Ogula, 2012 reiterated that the attitude, perception and behavior of host community is a key factor that will enhance the activities of developmental agencies in the Niger Delta. Based on the respondents' disclosure on the attitude of community members, it will create awareness to government, policy makers and developmental agencies on the need to take into cognizance the relevance of community members in development initiatives. Another impediment identified is leadership problem both at the community level and NDDC. Community members and NDDC officers identified 
leadership problem as a major impediment. In view of these, the understanding of these issues could hold lessons for government, developmental agencies and community themselves. Sustainable community development should be about the improvement and betterment of community members and sustainability in their immediate environment. In line with the study's objective, it was revealed that abandonment of projects has been recognized as one of the impediment to human development and by extension the source of restiveness in the area. Furthermore, this study also identified lack of adequate funding, community attitude and leadership style as challenges to sustainable development in the Niger Delta.

\section{References}

Agbiboa, D. E. (2013). Have we heard the last? Oil, environmental insecurity, and the impact of the amnesty programme on the Niger Delta resistance movement. Review of African Political Economy, 40(137), 447-465.

Agbu, (2012) NDDC and the challenges of abandoned projects. Retrieved July 2, 2015 from http://nigeriamasterweb.com/blog/index. php/2012/09/11/nigeria-nddc-and-the-challenge-of-abandoned-projects.

Aghedo, I. (2013). Winning the war, losing the peace: amnesty and the challenges of post-conflict peace-building in the Niger Delta, Nigeria. Journal of Asian and African Studies, 48(3), 267-280.

Akpabio, M.E and Akpan, N.S (2010) Governance and oil politics in Nigeria's Niger Delta: The Question of Distributive Equity. Journal of Human Ecology, 30(2), 111-121.

Akpomuvie B.O. (2011). Breaking Barriers to transformation of the Niger Delta Region of Nigeria: A Human Development Paradigm Journal of Sustainable 4 (3) pp $1-15$.

Akpomuvie, O. (2011). Tragedy of Commons: Analysis of Oil Spillage, Gas Flaring and Sustainable Development of the Niger Delta of Nigeria. Journal of Sustainable Development, 4(2), p200.

Alkire, S. (2002). Dimensions of human development. World development, 30(2), 181-205.

Amartya, S. (2005). Human Rights and Capabilities: Journal of Human Development, volume 6, Issue 2. Routledge. Publishers.

Andreasson, S. (2011). Understanding corporate governance reform in South Africa Anglo-American divergence, the King Reports, and hybridization .Business \& Society, 50(4), 647-673.

Apsan Frediani, A., Boni, A., \& Gasper, D. (2014). Approaching development projects from a human development and capability perspective. Journal of Human Development and Capabilities, 15(1), 1-12.

Assante, L. M., Wen, H. I., Lottig, K., \& Hotels, S. (2012). An empirical assessment of residents' attitudes for sustainable tourism development: a case study of $O$ 'ahu, Hawaii. Journal of Sustainability and Green Business, 1(1), 1-27.

Babatunde, A. O. (2012). An Analytical Evaluation of the Cost of the Conflict in Nigeria's Niger Delta. Journal of Conflictology, 3(1).

Chandler, (2013).Human-centered Development? Rethinking freedom and Agency in discourses of International Development. SAGE Publications Itd.

Chinyere, I. E., \& Stephen, E. A. (2013). Resource Allocation and Sustainable Development in the Niger Delta: A Study of Obagi Rivers State Nigeria. Journal of International Diversity, (3).

Courson, E. (2011). MEND: Political Marginalization, Repression, and Petro-Insurgency in the Niger Delta. African Security, 4(1), 20-43.

Davidheiser, M., \& Nyiayaana, K. (2011). Demobilization or Remobilization? The Amnesty Program and the Search for Peace in the Niger Delta. African Security, 4(1), 44-64.

Demals, T., \& Hyard, A. (2014). Is Amartya Sen's sustainable freedom a broader vision of sustainability?. Ecological Economics, 102, 33-38.

Dietz, T., \& Jorgenson, A. K. (2014). Towards a new view of sustainable development: human well-being and environmental stress. Environmental Research Letters, 9(3), 031001.

Dode, R. O. (2012). The political economy of resource curse and the Niger Delta crisis in Nigeria: Matters arising. European Journal of Sustainable Development, 1(2), 235-248.

Dokpesi, A. \& Ibiezugbe. (2012): Assessing the Human development efforts of NDDC Journal of National Resources conflict and sustainable development: Routledge publishers.

Duru, E. J., \& Ogbonnaya, U. M. (2012). The Poverty of Crisis Management Strategies in the Niger Delta Region of Nigeria: A Focus on the Amnesty Programme. African Research Review, 6(2), 162-170.

Ehrhardt-Martinez, K., \& Laitner, J. A. (2010, August). Rebound, technology and people: mitigating the rebound effect with energyresource management and people-centered initiatives. In ACEEE summer study on energy efficiency in buildings.

Eneh, O. C. (2011). Crippling poverty amidst corporate social actions: A critique of peripheral corporate community involvement in the Niger Delta region of Nigeria. Asian J. Rural Development, 1, 120.

Fukuda-Parr, S. (2011). Theory and policy in international development: human development and capability approach and the millennium development goals. International Studies Review, 13(1), 122-132.

Gilbert, L. D. (2013). Revisiting Ethno-Nationalism in the Niger Delta of Nigeria: An Interrogation of its Achievements and Prospects. International Affairs and Global Strategy, 16, 50-56.

Gries, T., \& Naudé, W (2011). Entrepreneurship and human development: A capability approach. Journal of Public Economics, 95(3), 216-224.

Hanafiah, M. H., Jamaluddin, M. R., \& Zulkifly, M. I. (2013). Local Community Attitude and Support towards Tourism Development in Tioman Island, Malaysia. Procedia-Social and Behavioral Sciences, 105, 792-800. 
Hundred and Sixth Annual Meeting of the American Economic Association pp.

Ibaba, I. S (2011). Nigeria's Niger Delta: Militia Violence, Amnesty, and Energy Security'. Mark A. Mattaini and Kristen Atkinson, 18(1), 44.

Ingwe, R., Mboto, W. A., \& Ebong, E. E. (2012). Project abandonment, corruption and recovery of unspent budgeted public funds in Nigeria. Romanian Journal of Economics 1 (34), 24, 46.

Ite, U. E. (2007). Changing times and strategies: Shell's contribution to sustainable community development in the Niger Delta, Nigeria. Sustainable development, 15(1), 1-14.

Jack-Akhigbe, P., (2013). The State and Development Interventions in the Niger Delta Region of Nigeria International Journal of Humanities and Social Science Vol. 3 No. 10 Special Issue.

Kaur, S.(2013). Oil as a source of political conflict in Niger Delta. African Journal of Political Science and International Relations, 7(2), 33-37.

Knight, K. W. (2014). Temporal variation in the relationship between environmental demands and well-being: a panel analysis of developed and less-developed countries. Population and Environment, 36(1), 32-47.

Mahbub, U (2006). The Human development paradigm in S. Fukuda Parr and A.K. Shiva Kumar Eds. (2003).Readings in Human development. Oxford University Press.

Mähler, A. (2012). An inescapable curse? Resource management, violent conflict, and peacebuilding in the Niger Delta. High-value natural resources and post-conflict peacebuilding.

Naanen, B. (2012). The Nigerian State, Multinational Oil Corporations, and the Indigenous Communities of the Niger Delta. The Politics of Resource Extraction: Indigenous Peoples, Multinational Corporations and the State, 153.

Nussbaum, M. C. (2001). Women and human development: The capabilities approach (Vol. 3). Cambridge University Press.

Obi, C. (2014). Oil and the Post-Amnesty Programme (PAP): what prospects for sustainable development and peace in the Niger Delta? Review of African Political Economy, 41(140), 249-263.

Ogula, D. (2012). Corporate social responsibility: case study of community expectations and the administrative systems, Niger Delta. The Qualitative Report, 17(37), 1-27.

Ojo, S (2012). Amnesty Programme, Niger Delta militancy and the place of trust. Int. J. Science \& Knowledge; Vol, 1(1), 38-46.

Okpo, O. C., \& Eze, R. C. (2012). Vandalization of Oil Pipelines in the Niger Delta Region of Nigeria and Poverty: An Overview. Studies in Sociology of Science, 3(2).

Okumagba, P. (2011). Oil Exploration and Ethnic Militia activities in the Niger Delta Region of

Ololajulo, Babajide.O. (2000).Rural Development intervention and the challenges of sustainable livelihood in an oil producing Area of Nigeria. Kroeber Anthropological Society of Nigeria. Vol. 99/100.

Oluwaniyi, O. O. (2010). Oil and youth militancy in Nigeria's Niger Delta Region. Journal of Asian and African Studies, 45(3), 309-325.

Osuoka, A. I. (2007, September). Oil and gas revenues and development challenges for the Niger Delta and Nigeria. In expert group meeting on the use of non-renewable resource revenues for sustainable local development. Organized by the UN Department of Economic and Social Affairs, UN Headquarters, New York (Vol. 21).

Oviasuyi, and Uwadias, J. (2010).The Dilemma of the Niger Delta Region as oil producing states in Nigeria: Journal of Peace, Conflict and Development, Issues 16.

Paki an Ebienfa, 2011: Oil and Development in Africa: Failure of Intervention Agencies in Nigeria's Niger Delta: International Journal of Business and Social Sciences Vol 2, No 8, 2011.

Seedat, M., \& Lazarus, S. (2011). Community psychology in South Africa: Origins, developments, and manifestations. Journal of community psychology, 39(3), 241-257.

Sen, A. (2005). Human rights and capabilities. Journal of Human Development, 6(2), 151-166.

The American Economic Review, (May, 1994). Vol. 84, No. 2, Papers and Proceedings of the 232-237 Published by: American Economic Association Stable URL: http://www.jstor.org/stable/2117835. Accessed: 07/04/2015 08:31PM.

Thomas, T., Narayanan, P., Wheeler, T., Kiran, U., Joseph, M. J., \& Ramanathan, T. V. (2012). Design of a Community Ownership and Preparedness Index: using data to inform the capacity development of community-based groups. Journal of epidemiology and community health, 66(Supply 2), ii26-ii33.

Ubhenin, O.E (2013): The federal Government's Amnesty Programme in the Niger Delta: An appraisal. Yonetim Bilimleri Dergisi Olt: 11, Sayi: 21, ss.199-203.

Ukiwo, U. (2011). The Nigerian State, Oil and the Niger Delta. Oil and Insurgency in the Niger Delta: Managing the complex politics of petro-violence. London/New York: Zed Books. 